\title{
WHODAS and the evaluation of disability among people with mental disorders with and without psychotic symptoms
}

\author{
Omar Hernández-Orduña, ${ }^{1}$ Rebeca Robles-García, ${ }^{2}$ Nicolás Martínez-López, ${ }^{3}$ Carolina Muñoz-Toledo, ${ }^{1}$ \\ Alejandra González-Salas, ${ }^{4}$ María Cabello, ${ }^{5}$ Tecelli Domínguez-Martínez, ${ }^{6}$ María Elena Medina-Mora ${ }^{4}$
}

1 Facultad de Psicología, Universidad Nacional Autónoma de México, Ciudad de México, México.

2 Departamento de Modelos de Intervención, Dirección de Investigaciones Epidemiológicas y Psicosociales, Instituto Nacional de Psiquiatría Ramón de la Fuente Muñiz, Ciudad de México, México.

${ }^{3}$ Departamento de Epidemiología Clínica, Subdirección de Investigaciones Clínicas, Instituto Nacional de Psiquiatría Ramón de la Fuente Muñiz, Ciudad de México, México.

${ }^{4}$ Dirección General, Instituto Nacional de Psiquiatría Ramón de la Fuente Muñiz, Ciudad de México, México.

5 Unidad CIBER de Salud Mental (CIBERSAM), Universidad Autónoma de Madrid, Madrid, España.

${ }^{6}$ CONACYT - Departamento de Modelos de Intervención. Dirección de Investigaciones Epidemiológicas y Psicosociales, Instituto Nacional de Psiquiatría Ramón de la Fuente Muñiz, Ciudad de México, México.

Correspondence:

Rebeca Robles-García

Departamento de Modelos de Intervención, Dirección de Investigaciones Epidemiológicas y Psicosociales, Instituto Nacional de Psiquiatría Ramón de la Fuente Muñiz.

Calz. México-Xochimilco 101, Col. San Lorenzo Huipulco, Del. Tlalpan, C.P. 14370, Ciudad de México, México

Phone: 41605143

Email: reberobles@imp.edu.mx

Received first version: March 3, 2017

Second version: August 16, 2017

Accepted: September 7, 2017

doi.10.17711/SM.0185-3325.2017.027

\begin{abstract}
Introduction. Valid and feasible measures to properly assess the most impaired areas of functioning in various groups of patients with mental disorders would allow the development and evaluation of interventions designed to modify the specific environmental barriers that contribute to patients' disability. Objective. This article seeks to evaluate the internal consistency and construct and convergent validity of the Spanish version of the World Health Organization's Disability Assessment Schedule WHODAS 2.0, as well as its relationship with sociodemographic variables and symptomatic severity in Mexican patients with and without psychotic symptoms. Method. The WHODAS 2.0 and the Social and Occupational Functioning Assessment Scale SOFAS were administered to 153 patients with any of the following diagnoses: affective disorders, anxiety disorders, stress-related disorders, and psychotic disorders. Results. The WHODAS 2.0 showed high internal consistency in patients with psychotic symptoms (Cronbach's alpha $=.92$ ) and without psychotic symptoms (Cronbach's alpha $=.89$ ). Nevertheless, only in patients without psychotic symptoms, was a significant negative correlation between WHODAS (disability) and SOFAS (functioning) total scores observed, together with significant differences in WHODAS scores between those with mild and severe symptomatology. Discussion and conclusion. The WHODAS 2.0 is an adequate measure of disability in patients without psychotic symptoms. It could be used as a complementary measure of disability in those with psychotic symptoms. Further studies are required to determine other psychometric properties of the WHODAS 2.0, particularly those related to temporal stability and sensitivity to change.
\end{abstract}

Keywords: Disability, functioning, mental disorders, evaluation, self-report, WHODAS.

\section{RESUMEN}

Introducción. Disponer de medidas válidas y confiables para evaluar las áreas de funcionamiento más comprometidas en los diferentes grupos de pacientes con trastornos mentales permitiría el desarrollo y la evaluación de intervenciones dirigidas a modificar barreras específicas del contexto que contribuyen a su deterioro funcional. Objetivo. Evaluar la consistencia interna y la validez de constructo y convergente de la versión en español del cuestionario para la evaluación de discapacidad de la Organización Mundial de la Salud WHODAS 2.0, así como su relación con variables demográficas y la gravedad sintomática en pacientes mexicanos con y sin síntomas psicóticos. Método. EI WHODAS y la escala de evaluación del funcionamiento social y ocupacional SOFAS se aplicaron a una muestra de 153 pacientes con algún diagnóstico de trastorno afectivo, de ansiedad, relacionado con el estrés o psicótico. Resultados. EI WHODAS mostró alta consistencia interna en pacientes con síntomas psicóticos (alpha de Cronbach $=.92$ ) y en aquellos sin síntomas psicóticos (alpha de Cronbach $=.89$ ). Sin embargo, sólo en los pacientes sin síntomas psicóticos se observó una correlación negativa entre las puntuaciones del WHODAS 2.0 (discapacidad) y el SOFAS (funcionalidad) así como diferencias significativas en las puntuaciones WHODAS de aquellos con sintomática leve y grave. Discusión y conclusión. La escala WHODAS 2.0 es adecuada para medir discapacidad en pacientes sin síntomas psicóticos. En aquellos con síntomas psicóticos, podría servir más bien con fines complementarios. Se sugieren estudios para determinar otras propiedades psicométricas del WHODAS, especialmente las relacionadas con su estabilidad temporal y sensibilidad al cambio.

Palabras clave: Discapacidad, funcionalidad, trastornos mentales, evaluación, autorreporte, WHODAS. 


\section{INTRODUCTION}

According to the World Health Organization (WHO), the concept of disability refers to a degree of functional impairment at the bodily and social and environmental levels (involving everyday activities and social participation) (Organización Mundial de la Salud \& Organización Panamericana de la Salud, 2001). Thus, disability is a key indicator of health status, since it not only combines the consequences of the physical deterioration caused by illness or injury, but also the impact of social and environmental barriers that can be modified through particular interventions. Hence the relevance of their proper measurement to determine the most heavily compromised areas in specific patient populations.

Disability is on the rise. In 2010, more than one billion people had some form of disability, equivalent to $15 \%$ of the world's population. This figure is $10 \%$ higher than expected for that year according to previous estimates (Organización Mundial de la Salud \& Organización Panamericana de la Salud, 2001). This increase may be due to the attention given to assessing the loss of functionality, and even to gauging the world burden of disease. In fact, this was how mental disorders were shown to constitute significant public health problems worldwide (Murray et al., 2013).

\section{Assessment of disability in people with mental disorders}

In the 1980s, the use of the Global Assessment of Functioning (GAF) scale was proposed to evaluate treatment outcomes and the level of improvement or deterioration in the functioning of patients with mental disorders, one of its greatest advantages being sensitivity to changes over time. However, the scores assigned are often related more to the severity of symptoms than to levels of impairment or disability, with which they do not necessarily show congruence (Goldman, Skodol, \& Lave, 1992).

Conversely, the Social and Occupational Functioning Assessment Scale (SOFAS) ignores the influence of the severity of symptoms (Morosini, Magliano, Brambilla, Ugolini, \& Pioli, 2000). However, since it is only a cross-sectional evaluation, it does not take into account the time of evolution of the disorder -as, for example, the Personal and Social Performance (PSP) does (Apiquian et al., 2009).

Currently, one of the most commonly used instruments for assessing disability is the World Health Organization Disability Assessment Schedule (WHODAS) 2.0, since it is a general measure for comparing disability levels in various areas of functioning between different conditions and diseases (Gold, 2014). However, it is still necessary to compare the adequacy of this measure to evaluate populations with different mental disorders.

Patients with psychotic spectrum disorders often experience a chronic course with severe episodes, leading to significant alterations in functioning in virtually all areas of life (Gómez, Ender, Alvarado, Commetto, \& Fernández, 2015); whereas those with affective disorders tend to show an acute course, so that the impact on functioning in daily life may be less-although very considerable in terms of personal, family and social suffering and costs (Guerra et al., 2009).

In addition to variations in the severity of the disability depending on the mental disorder that is suffered, there may be differences in the areas of functioning affected. According to Lara, Medina-Mora, Borges, and Zambrano (2007), social relations is the area most severely compromised in patients with affective disorders, with depression causing the greatest impact on the average number of days with disability. This has been shown to be associated with high levels of impairment in the occupational area (including unemployment and decreased performance), comparable and even higher than those reported for other physical diseases (Benjet, Casanova, Borges, \& Medina-Mora, 2013; Hays, Wells, Sherbourne, Rogers, \& Spritzer, 1995; Romera, Perez, Menchón, Delgado-Cohen, Polavieja, \& Gilaberte, 2010).

Anxiety disorders are also among the main causes of years lost through disability worldwide (Vos et al., 2013), and there are differences in the level of effects on the areas of functioning with other diagnostic groups as well as between the different anxiety disorders (Mendlowicz \& Stein, 2000). In the study by Olfson et al. (1997), although depressive symptoms correlated with both social and family impairment and work disability, patients with panic symptoms showed significant functioning problems related to job loss and increased use of health services. Conversely, posttraumatic stress disorder has been associated more with functional impairment in the familial and social area, even in its partial or subclinical forms (Stein, Walker, Hazen, \& Forde, 1997).

People with psychotic disorders tend to have significant impairment in cognitive functioning, commonly associated not only with disability in social and occupational activities, but also those of a more basic order or involving survival (Velligan et al., 2008).

WHODAS is the instrument that allows the evaluation of the greatest number of operating dimensions in people with very diverse health problems. It has already been evaluated in different groups of mental disorders, showing adequate indexes of validity and reliability (Garin et al., 2010). However, there are few studies on its differential functioning in Mexican patients with and without psychotic symptoms. This information is relevant for decision-making as to whether or not to use a self-report disability measure such as WHODAS in both general patient groups. It could be hypothesized that individuals with psychotic symptoms would provide less reliable reports given the cognitive deficit they frequently present (Alptekin et al., 2005; McKibbin, Patterson, \& Jeste, 2004). 
Accordingly, the main objective of this study was to determine and compare the convergent and construct validity as well as the internal consistency of the total and the dimensions of the second Spanish version of WHODAS 2.0 in Mexican patients with and without psychotic symptoms. Additionally, the relationship between patients' perception of disability and their demographic and characteristics and symptomatic severity was evaluated.

\section{METHOD}

\section{Subjects}

Patients at the Instituto Nacional de Psiquiatría Ramón de la Fuente Muñiz (National Institute of Psychiatry) in Mexico City, who were referred by the clinicians in the pre-consultation area after their initial evaluation at the institution, with the presumptive diagnosis of certain affective or anxiety disorders, related to stress or psychosis, and whose diagnosis was corroborated by a psychiatrist after a clinical interview based on the guidelines proposed for ICD-11 (as part of the ICD-10 revision project) (World Health Organization, 1995).

In all cases, they were men or women of legal age who had agreed to participate in the study and signed the corresponding informed consent form. Patients with physical or neurological problems that affected their ability to communicate, those with mental disorders following medical conditions or trauma, and those who turned up for the evaluation in a state of intoxication, agitation, or suicide ideation were excluded.

Since the main objective of the study was the psychometric evaluation of WHODAS in patients with and without psychotic symptoms, the sample size of this study would be considered adequate if it satisfied a minimum of 50 subjects per group (with/without psychotic symptoms), equivalent to the number of items in the WHODAS dimension with the highest number of items $(10$, in the sub-scale of activities in everyday living) multiplied by a number of five respondents, according to the recommendation of Crocker and Algina (1986).

\section{Instruments}

The second version of WHODAS 2.0 in Spanish used in this study, developed by Vázquez-Barquero et al. (1999) and adapted to Latin American Spanish by Matías-Carrelo, Chavez, Negrón, Canino, Aguilar-Gaxiola, and Hoppe (2003), is a semi-structured interview to explore everyday functioning in six areas: understanding and communication, the ability to move around in one's environment, personal care, the ability to relate to other people, everyday activities (at home, or at school/work), and participation in society.
It provides an objective profile of functioning and the subjective perception of the patient on the impact his or her illness produces in each one of the areas, with a higher score indicating greater disability. It consists of 38 items with 5-point Likert responses, where 1 refers to no disability in performing the activity and 5 to a total inability to perform the activity.

Two types of scores were obtained, referring to each sub-scale and a global score. The subscales are composed of different numbers of items (see first column of Table 1); the subscale of activities in everyday life provides the option of using all the items in the subscale (10 in total) if the person, in addition to his/her household activities, is studying or working, or of only using household-related activities (4 in total) provided he/she does not go to school or work. For this reason, it is necessary to convert the initial scores by taking into account the importance of each item according to the score manual (Vázquez-Barquero, Herrera, Vázquez, \& Gaite, 2006). To facilitate the interpretation of the subscale and total scores, these are converted into scores from 0 to 100. Üstün et al. (2010) confirmed that WHODAS 2.0 has a Cronbach's alpha global internal consistency of 0.86 (ranging from 0.82 to 0.98 for its different subscales), one-week test-retest reliability of 0.98 , and good concurrent validity with other instruments measuring a similar concept of disability (Sartorius \& Üstün, 1995; Harwood, Rogers, Dickinson, \& Ebrahim, 1994; Granger, Hamilton, Linacre, Heinemann, \& Wright, 1993; Ware Jr, Kosinski, \& Keller, 1996).

SOFAS is a modified version of GAF incorporated into the V Axis of the DSM-IV (American Psychiatric Association, 2000). It is therefore a measure specifically designed to evaluate the functionality of people with mental disorders, where deterioration is evident in the loss of skills for proper performance in four areas: social role, self-care, autonomy, and coping (Goldman et al., 1992). SOFAS is scored on a 100-point scale according to the individual's level of social and occupational functioning on a continuum ranging from a state of significant functional impairment to an optimal functioning level. Most outpatients are rated at between 31 and 70 , whereas a large proportion of hospitalized patients score between 1 and 40 (Gómez et al., 2015; Romera et al., 2010). The highest levels in the SOFAS assessment describe individuals who do not present significant psychopathology and exhibit many positive mental health traits or components (Romera et al., 2010; Spitzer, Gibbon, \& Endicott, 2000). The scale should be applied by a clinician, using information from any source (such as medical history and interviews). Thus, SOFAS scores correspond to the clinician's subjective impression in relation to the patient's functioning.

Lastly, the evaluation of symptomatic severity was carried out by two psychiatrists after a diagnostic interview with the patient (lasting approximately one hour). The total score was recorded on a five-point Likert scale where $1=$ no symptoms, $2=$ mild symptoms, $3=$ moderate symptoms, $4=$ severe 
Table 1

Internal consistency of WHODAS scores in total sample and study groups

\begin{tabular}{lcccc}
\hline & $\begin{array}{c}\text { Number of items } \\
\text { in scale and subscales }\end{array}$ & $\begin{array}{c}\text { Patients with } \\
\text { psychotic symptoms } \\
n=53\end{array}$ & $\begin{array}{c}\text { Patients without } \\
\text { psychotic symptoms } \\
n=100\end{array}$ & $\begin{array}{c}\text { Total sample } \\
n=153\end{array}$ \\
\hline Total score & 38 & .92 & .89 & .91 \\
Communication and understanding & 6 & .69 & .67 & .69 \\
Moving around in one's environment & 5 & .54 & .75 & .72 \\
Personal care & 4 & .56 & .55 & .55 \\
Interpersonal relations & 5 & .86 & .63 & .62 \\
Household activities & 4 & .86 & .78 & .82 \\
Work/school activities & 6 & .71 & .90 & .90 \\
Participation in society & 8 & .73 & .73 \\
\hline
\end{tabular}

symptoms, and $5=$ extremely severe symptoms. To confirm the usefulness of this evaluation in the present study, the correlations between two raters and the SOFAS were calculated. The results are given in the corresponding section of this text. In general, it achieves adequate inter-rater reliability and convergent validity, so it was decided to use it as a method of evaluation of this variable in the study.

\section{Procedure}

This study derives from a larger project, previously approved by the research ethics committees of the Instituto Nacional de Psiquiatría Ramón de la Fuente Muñiz (see data in funding section).

WHODAS 2.0 was applied by psychologists previously trained by a certified expert from the Universidad Autónoma de Madrid, María Cabello (Autonomous University of Madrid), until they achieved an inter-rater reliability of over .85 (each assistant with the certified expert).

Patients were subsequently evaluated by two psychiatrists, one of whom acted as an interviewer and the oth- er as an observer. At the end of the diagnostic interview, both clinicians independently completed the evaluation of the functionality of each patient based on SOFAS, and their symptomatic severity through the ad hoc Likert scale for the study.

\section{Data analysis}

Data were analyzed using the SPSS-X version 21 package, for Windows, PC The descriptive analyses were conducted on the basis of means, standard deviations and range for the continuous variables, and with frequencies and percentages for the categorical variables. Chi square or T-Student tests of independent samples were used to determine whether there were differences in sociodemographic variables, symptom severity, and WHODAS and SOFAS scores among groups of patients with and without psychotic symptoms. Pearson and Spearman correlations were used to evaluate the associations between the different study variables (according to their measurement levels). Cronbach's alpha coefficients were calculated to evaluate the internal consistency of the

Table 2

Socio-demographic variables of the total sample and study groups

\begin{tabular}{|c|c|c|c|c|}
\hline Variable & $\begin{array}{c}\text { Total sample } \\
n=153\end{array}$ & $\begin{array}{c}\text { Patients with } \\
\text { psychotic symptoms } \\
n=53\end{array}$ & $\begin{array}{c}\text { Patients without } \\
\text { psychotic symptoms } \\
n=100\end{array}$ & $\begin{array}{l}\text { Measures of comparison } \\
\text { between groups }\end{array}$ \\
\hline \multicolumn{5}{|l|}{$\operatorname{Sex}[n(\%)]$} \\
\hline Male & $44 \quad(28.8)$ & $26(49.1)$ & $18(18)$ & \multirow[t]{2}{*}{$\chi^{2}=16.30 ; \mathrm{df}=1 p \leq .0001$} \\
\hline Female & $109(71.2)$ & $27 \quad(50.9)$ & $82(82)$ & \\
\hline \multicolumn{5}{|l|}{ Age } \\
\hline $\begin{array}{l}\text { Mean + SD } \\
\text { Range }\end{array}$ & $\begin{array}{c}37.76 \pm 12.744 \\
(18-74)\end{array}$ & $\begin{array}{c}36.32 \pm 11.70 \\
(18-60)\end{array}$ & $\begin{array}{c}38.53 \pm 13.25 \\
\quad(18-74)\end{array}$ & NS \\
\hline \multicolumn{5}{|c|}{ Marital status $[n(\%)]$} \\
\hline Partnered & $44 \quad(28.8)$ & $5 \quad(9.43)$ & 39 (39) & \multirow[t]{2}{*}{$\chi^{2}=14.68 ; \mathrm{df}=1 p \leq .0001$} \\
\hline Unpartnered & 109 (71.2) & $48 \quad(90.56)$ & 61 (61) & \\
\hline \multicolumn{5}{|c|}{ Educational attainment } \\
\hline $\begin{array}{l}\text { Mean + SD } \\
\text { Range }\end{array}$ & $\begin{array}{c}12.50 \pm 3.356 \\
(0-18)\end{array}$ & $\begin{array}{l}12.42 \pm 3.284 \\
(6-18)\end{array}$ & $\begin{array}{l}12.55 \pm 3.40 \\
(0-18)\end{array}$ & NS \\
\hline \multicolumn{5}{|c|}{ Employment status [ $n(\%)]$} \\
\hline Work/school & 81 (52.9) & $25(47.2)$ & $56(56)$ & \multirow{2}{*}{ NS } \\
\hline No job/school & $72(47.1)$ & $28(52.8)$ & 44 (44) & \\
\hline
\end{tabular}


different dimensions and the total score of the WHODAS 2.0. In all cases, predefined alpha levels were set at $95 \%$. Lastly, in order to compare WHODAS scores between the different levels of symptomatic severity of the patients, they were divided into three groups according to the rating given by the evaluating clinician: 1. mild (scores of 1 and 2 on the symptomatic severity scale), 2. moderate (score of 3 in symptomatic severity), and 3. severe (scores of 4 and 5 on the symptomatic severity scale), as did Garin et al. (2010). The comparison of total WHODAS scores between these three severity levels was performed using a Bonferroni-corrected ANOVA for each of the patient groups (with and without psychotic symptoms).

\section{RESULTS}

Of the 232 patients referred, a total of 79 did not participate in the evaluation because they failed to attend the evaluation appointment $(n=46)$, had at least one of the exclusion criteria $(n=1)$, or did not agree to sign the letter of informed consent $(n=32)$. Thus, the final sample consisted of a total of 153 patients: $65.3 \%(n=100)$ had some affective, anxiety, or stress-related disorder, and no psychotic symptoms, while the remaining 34.6\% $(n=53)$ had some psychotic disorder or other affective, anxiety, or stress-related disorder with psychotic symptoms. Two study groups were then formed: 1. patients without psychotic symptoms (with affective, anxiety, or stress-related disorders) and 2. patients with psychotic symptoms (with psychotic disorders).

The percentage of women was higher for the group of patients without psychotic symptoms, compared to patients with psychotic symptoms $\left(\chi^{2}=16.30 ; \mathrm{df}=1 ; p \leq .0001\right)$; while the group of patients without psychotic symptoms reported having a partner (whether they were married or living together) more frequently than those with psychotic symptoms $\left(\chi^{2}=14.68 ; \mathrm{df}=1 ; p \leq .0001\right)$. Table 2 shows the sociodemographic characteristics of the total sample and by diagnostic groups (with or without psychotic symptoms).

\section{Internal consistency of WHODAS}

In the internal consistency analysis of the WHODAS scales and subscales, high coefficients were recorded for the total

Table 3

Disability, functionality and symptomatic severity: Description and comparison between groups of patients with and without psychotic symptoms

\begin{tabular}{|c|c|c|c|c|}
\hline Variable & $\begin{array}{c}\text { Total Sample } \\
n=153\end{array}$ & $\begin{array}{l}\text { Patients with } \\
\text { psychotic symptoms } \\
\qquad n=53\end{array}$ & $\begin{array}{c}\text { Patients without } \\
\text { psychotic symptoms } \\
n=100\end{array}$ & $\begin{array}{c}\text { Measures of comparison } \\
\text { between groups }\end{array}$ \\
\hline \multicolumn{5}{|l|}{ WHODAS [mean \pm SD (range)] } \\
\hline Total score & $\begin{array}{l}44.70 \pm 17.46 \\
(5.21-95.65)\end{array}$ & $\begin{array}{c}38.68 \pm 16.36 \\
(15.38-76.14)\end{array}$ & $\begin{array}{l}47.89 \pm 17.25 \\
(5.21+95.65)\end{array}$ & $\begin{array}{c}\mathrm{t}=-3.252 ; \mathrm{df}=111.06 \\
p=.002\end{array}$ \\
\hline Communication and understanding & $\begin{array}{c}41.75 \pm 19.25 \\
(0-85)\end{array}$ & $\begin{array}{c}37.57 \pm 19.79 \\
(0-81.25)\end{array}$ & $\begin{array}{c}43.96 \pm 18.67 \\
(0-85)\end{array}$ & $\begin{array}{c}\mathrm{t}=-1.938 ; \mathrm{df}=100.87 \\
p=.055\end{array}$ \\
\hline Movement in the environment & $\begin{array}{c}34.59 \pm 24.29 \\
(0-100)\end{array}$ & $\begin{array}{c}29.95 \pm 21.52 \\
(0-81.25)\end{array}$ & $\begin{array}{c}37.06+25.39 \\
(0-100)\end{array}$ & NS \\
\hline Personal care & $\begin{array}{c}30.78 \pm 22.63 \\
(0-100)\end{array}$ & $\begin{array}{c}23.16 \pm 19.22 \\
(0-80)\end{array}$ & $\begin{array}{c}34.82 \pm 23.33 \\
(0-100)\end{array}$ & $\begin{array}{c}\mathrm{t}=-3.310 ; \mathrm{df}=124.92 \\
p=.001\end{array}$ \\
\hline Interpersonal relations & $\begin{array}{c}47.51 \pm 28.38 \\
(0-100)\end{array}$ & $\begin{array}{l}44.43 \pm 29.13 \\
(0-100)\end{array}$ & $\begin{array}{c}34.82 \pm 27.99 \\
(0-100)\end{array}$ & NS \\
\hline Everyday activities at home & $\begin{array}{c}46.47 \pm 31.61 \\
(0-100)\end{array}$ & $\begin{array}{c}37.35 \pm 32.59 \\
(0-100)\end{array}$ & $\begin{array}{c}51.30 \pm 32.62 \\
(0-100)\end{array}$ & $\begin{array}{c}\mathrm{t}=-2.583 ; \mathrm{df}=99.12 \\
p=.011\end{array}$ \\
\hline Work/school & $\begin{array}{l}22.68 \pm 30.05 \\
\quad(0-100)\end{array}$ & $\begin{array}{c}14.55 \pm 22.58 \\
(0-85.71)\end{array}$ & $\begin{array}{l}27.00 \pm 30.13 \\
(0-100)\end{array}$ & $\begin{array}{c}\mathrm{t}=-2.478 ; \mathrm{df}=151 \\
p=.014\end{array}$ \\
\hline Participation in society & $\begin{array}{c}57.64 \pm 20.09 \\
(8.33-100)\end{array}$ & $\begin{array}{l}51.04 \pm 19.88 \\
(18.18-100)\end{array}$ & $\begin{array}{c}61.14 \pm 19.39 \\
(8.33-100)\end{array}$ & $\begin{array}{c}\mathrm{t}=-3.013 ; \mathrm{df}=103.79 \\
p=.003\end{array}$ \\
\hline \multicolumn{5}{|l|}{ SOFAS [mean \pm SD (range)] } \\
\hline Rater & $\begin{array}{c}53.57 \pm 12.31 \\
\quad(15-82)\end{array}$ & $\begin{array}{l}47.62 \pm 11.46 \\
(15-65)\end{array}$ & $\begin{array}{l}56.72 \pm 11.60 \\
\quad(31-82)\end{array}$ & $\begin{array}{c}\mathrm{t}=-4.650 ; \mathrm{df}=107.18 \\
p \leq .0001\end{array}$ \\
\hline Observer & $\begin{array}{c}55.58 \pm 12.79 \\
(25-90)\end{array}$ & $\begin{array}{c}49.34 \pm 13.95 \\
(25-78)\end{array}$ & $\begin{array}{c}58.88 \pm 10.81 \\
(30-90)\end{array}$ & $\begin{array}{c}\mathrm{t}=-4.683 ; \mathrm{df}=151 \\
p \leq .0001\end{array}$ \\
\hline \multicolumn{5}{|l|}{ Symptomatic gravity [mean \pm SD (range)] } \\
\hline Rater & $\begin{array}{l}3.18 \pm .68 \\
\quad(2-5)\end{array}$ & $\begin{array}{l}3.13 \pm .81 \\
\quad(2-5)\end{array}$ & $\begin{array}{l}3.21 \pm .60 \\
\quad(2-5)\end{array}$ & NS \\
\hline Observer & $\begin{array}{l}3.12 \pm .79 \\
\quad(1-5)\end{array}$ & $\begin{array}{l}3.17 \pm 1.03 \\
\quad(1-5)\end{array}$ & $\begin{array}{l}3.10 \pm .64 \\
\quad(1-4)\end{array}$ & NS \\
\hline
\end{tabular}

Note: $\mathrm{SD}=$ Standard deviation; $\mathrm{df}=$ degrees of freedom; $\mathrm{NS}=$ Not significant. 
Table 4

WHODAS-SOFAS Pearson Correlations in total sample and study groups

\begin{tabular}{lccc}
\hline & $\begin{array}{c}\text { Patients with } \\
\text { psychotic symptoms } \\
n=53\end{array}$ & $\begin{array}{c}\text { Patients without } \\
\text { psychotic symptoms } \\
n=100\end{array}$ & $\begin{array}{c}\text { Total sample } \\
n=153\end{array}$ \\
\hline Total WHODAS - SOFAS Rater & $r=-.008$ & $r=-.245$ & $r=-.062$ \\
& $\mathrm{NS}$ & $p=.014$ & $\mathrm{NS}$ \\
Total WHODAS - SOFAS Observer & $r=-.108$ & $r=-.327$ & $r=-.126$ \\
& $\mathrm{NS}$ & $p=.001$ & $\mathrm{NS}$ \\
SOFAS Rater - SOFAS Observer & $r=.326$ & $r=.255$ & $r=.371$ \\
& $p=.017$ & $p=.011$ & $p \leq .0001$ \\
\hline
\end{tabular}

sample (.91) and the diagnostic group (.89 for the group without psychotic symptoms and .92 for the group with psychotic symptoms). Table 1 shows the Cronbach's alpha coefficients of each of the WHODAS subscales.

\section{Convergent validity of WHODAS with SOFAS}

The disability scores reported by patients with psychotic symptoms in the WHODAS-based interview were lower than those recorded by patients without psychotic symptoms-except for the area of interpersonal relationships. Conversely, according to clinician-rated functionality (SOFAS), patients with psychotic symptoms showed greater impairment of functioning than those without psychotic symptoms (Table 3). Moreover, although the WHODAS total score was statistically significantly associated with that of the SOFAS in the group of patients without psychotic symptoms, this was not the case for patients with psychotic symptoms (Table 4).

\section{WHODAS construct validity}

Figure 1 shows the average total scores of WHODAS according to the level of symptomatic severity (mild, moderate, or severe) for the two groups of patients (with and without psychotic symptoms).

As one can see, only statistically significant differences were found in the disability scores of mild and severe patients with no psychotic symptoms.

\section{Sociodemographic variables, symptomatic severity, and perception of disability}

In the total study sample, partnered patients (whether married or living together) reported higher total disability scores than those without a partner (single, divorced, separated, and widowed) (WHODAS with partner: $49.76+18.24$, WHODAS without partner: $42.66+16.79 ; t=2.231 ; \mathrm{df}=74.01$; $p=.029$ ).

Being partnered or otherwise was significantly related to gender $(86.4 \%$ of women had a partner, whereas in men this only occurred in $13.6 \%, \chi^{2}=6.89$; $\mathrm{df}=1 ; p=.009$ ), whereas gender was associated with the total WHODAS score (Rho Spearman $=-.212 ; p=.008$ ). The remaining demographic variables were not significantly related to the perceived disability of the total sample, or to the group of patients without psychotic symptoms.

The analysis restricted to patients with psychotic symptoms showed that self perception of disability was greater in those who were not engaged in paid employment (WHODAS without paid employment: $43.04+16.19$, WHODAS with paid employment: $33.79+15.44, t=-2.12 ; \mathrm{df}=50-76$; $p=.038)$.

Lastly, in relation to the symptomatic severity of the patient (according to the evaluation of the two participating clinicians), for the total of the sample, a positive, statistically significant correlation was found with the degree of disability perceived by patients (through WHODAS) (relationship between WHODAS and severity according to the evaluating

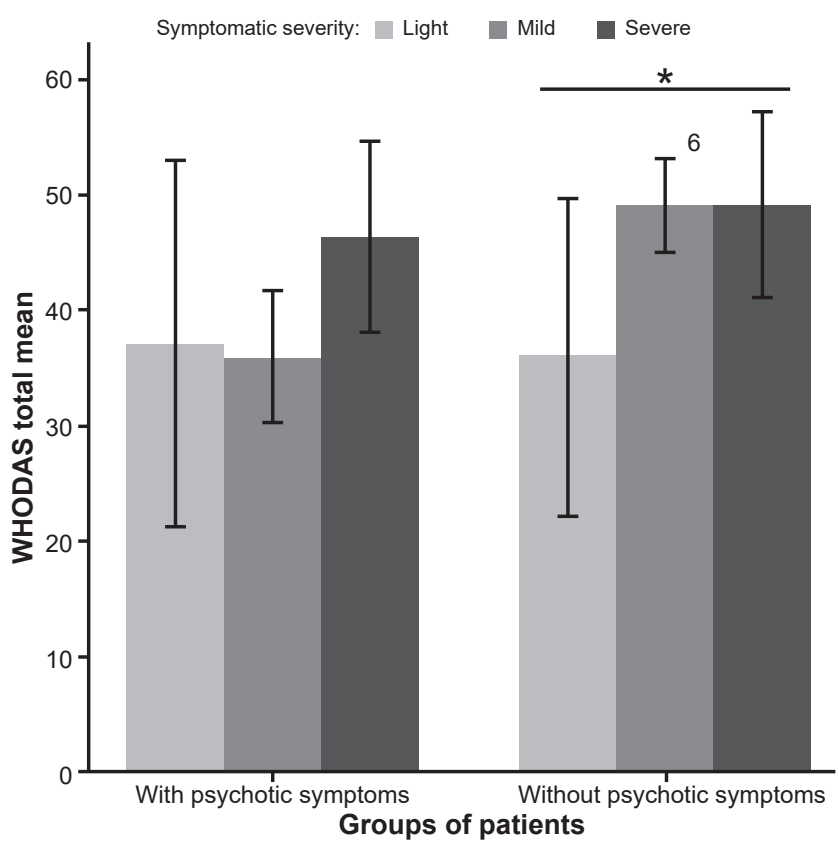

Figure 1. Total scores for each level of symptomatic severity by patient group (with and without psychotic symptoms). 95\% confidence intervals and intervals are presented; ${ }^{*} p \leq .05$. 
clinician: $r=.217 ; p=.007$; relationship between WHODAS and severity according to observing clinician: $r=.280$; $p \leq .0001)$. The same was true of the analysis by diagnostic groups (with or without psychotic symptoms).

It should be noted that the Likert scale scores for severity of the total sample by both clinicians correlated positively $(r=.28 ; p \leq .01)$, proving their inter-rater reliability. Moreover, they were negatively associated with disability scores through SOFAS ( $r=-.54$ for raters, and $r=-.64$ for observers, $p \leq .01$ in both cases), suggesting divergent validity for this form of evaluation of patient symptoms.

\section{DISCUSSION AND CONCLUSION}

The results of this study suggest that WHODAS 2.0 functions consistently in patients with mental disorders with or without psychotic symptoms. In general, according to Nunally's (1987) suggestion for the interpretation of Cronbach's alpha coefficients (to consider them high as from .70), the internal consistency indexes of the total scale were adequate for patients with mental disorders with or without psychotic symptoms who participated in this study. These findings are consistent with those obtained in other countries where very high rates of internal consistency of WHODAS have been obtained in patients with schizophrenia (Guilera et al., 2012) and depression (Chwastiak \& Von Korff, 2003).

In addition, coefficients hovered around .70 or greater for most subscales in both groups of patients, with the exception of the domains of "personal care" and "interpersonal relationships", with moderate (rather than high) consistencies of approximately .60. This may be because they are also among the scales with fewest items, which explains why the coefficients are similar in both groups of patients (Cervantes, 2005).

Moreover, for the group of patients without psychotic symptoms, a significant correlation was found between the evaluation using this tool and that performed by clinicians based on SOFAS. This association was, however, of a low magnitude (approximately .3), which implies a partial coincidence between the patient's perception of his degree of disability and that of the psychiatrist regarding his level of functioning. These data coincide with those previously observed in the Spanish population (Guilera et al., 2015).

As in the Spanish sample of patients with bipolar disorder, in the participants of our study with affective, anxiety, or stress-related disorders, the areas of greatest disability were the activities involving everyday living (basically at home) and social participation. As might be hypothesized, given the nature of the symptomatology characteristic of these conditions, patients with affective, anxiety, or stress-related disorders will find it more difficult to function socially because of the lack of desire to undertake activities involving interpersonal relationships.
Regarding the construct validity of WHODAS, it was observed that among patients with no psychotic symptoms, the total WHODAS score was higher for those with mild symptomatology compared to those with moderate and severe symptomatology.

At the same time, it is striking that the patients with psychotic symptoms included in this study perceived themselves as having less disability in almost all areas of functioning compared to patients without psychotic symptoms. In fact, in the group of patients with psychotic symptoms, there was no relationship between their assessment of disability with WHODAS 2.0 and that of functionality by the clinicians based on SOFAS.

These results are consistent with the study by Chopra, Couper, and Herrman (2004) which showed that patients with psychotic disorders minimized their problems in the areas of everyday living and self-care compared to clinical evaluations. It is probable that these patients, given the cognitive impairment that their symptoms imply, lacked clarity regarding the impact of their disease on their everyday functioning, as opposed to patients without psychotic symptoms (Guilera et al., 2015).

Furthermore, in this study, there were no significant differences in WHODAS scores among patients with mild, moderate, or severe symptoms. This data could be interpreted in two ways: questioning the WHODAS construct validity for this particular psychiatric population, or as additional evidence regarding the partial independence of symptomatic severity and levels of disability-the reason why the use of GAF for the assessment of functional impairment (Goldman et al., 1992) has been questioned.

As suggested in other studies, since WHODAS 2.0 is based on subjective patient perception, it may provide less reliable reports when used by individuals with cognitive deficits (McKibbin, Patterson, \& Jeste, 2004; Alptekin et al., 2005). On the other hand, the presence of symptoms such as delusions, suspicion, grandeur, and low attunement have also been related to an over-estimation of the self-reported performance level compared to evaluations by clinicians and third-party informants (Sabbag, Twamley, Vella, Heaton, Patterson, \& Harvey, 2012).

Either way, the patient's perception could be useful for building therapeutic alliances and commitment to treatment by patients with psychotic symptoms. It could also be useful in the design and implementation of therapeutic programs that address patients' needs. For example, since patients with psychotic symptoms perceived themselves to be more disabled if they did not have a paid job, functional rehabilitation programs targeting this population would have to devote special efforts to their job training.

In conclusion, the WHODAS 2.0 scale has proved to be an adequate measure of disability in terms of internal consistency and construct validity in patients with affective, anxiety, or stress-related disorders. In the case of 
those with psychotic symptoms, it also functions consistently and makes it possible to determine their subjective perception of disability, which, although it may not always coincide with that of a specialist clinician, may be useful for complementing the evaluation of this construct by taking into account both perspectives, that of the clinician and the patient.

\section{Limitations and suggestions}

In this study, a basic psychometric evaluation of WHODAS 2.0 was carried out, suggesting that future studies should be conducted to determine other measurement properties of this instrument, especially those related to temporal stability and sensitivity to change.

Although the sample size is adequate for the central objective of the study (in relation to the WHODAS psychometric evaluation), the descriptions of the disability level by area or functioning domain presented for each group of patients constitutes additional information which should be generalized with caution, in view of the fact that it is drawn from a sample of people seeking specialized care services in an urban area, who have higher average educational attainment than the general population.

At the very least, this is information which could have a certain heuristic value in promoting the implementation of complementary pharmacological treatments that would allow our patients to exercise their right to full, effective participation and inclusion in society and in community and civic life (Baumgartner \& Susser, 2013).

\section{Funding}

This study is derived from the general project called Validity and Clinical Utility of a New Taxonomy of Mental Disorders CIE11, WHO, funded by the Sectoral Fund for Research in Health and Social Security SS/IMSS/ISSSTECONACYT of the Consejo Nacional de Ciencia y Tecnología, Mexico (National Council for Science and Technology) (Project number: 23447, call for submissions 2014, principal investigator: Dra. Ma. Elena Medina-Mora).

\section{Conflict of interests}

The authors declare they have no conflict of interest.

\section{Acknowledgements}

Dra. Lucia Munch for her participation in applying the interviews to patients in the study as part of her role as research assistant in the overall project from which this study is derived.

\section{REFERENCES}

Alptekin, K., Erkoç, Ş., Göğüş, A. K., Kültür, S., Mete, L., Üçok, A., \& Yazııı, K. M. (2005). Disability in schizophrenia: Clinical correlates and prediction over 1-year follow-up. Psychiatry Research, 135(2), 103-111.

American Psychiatric Association. (2000). Appendix B: Criteria Sets and Axes Provided for Further Study. Diagnostic and Statistical Manual of Mental Disorders. 4th edition, text revision.
Apiquian, R., Elena U. R., Herrera-Estrella, M., Moreno-Gómez, A., Erosa, S., Contreras, V., Nicolini, H. (2009). Validity of the Spanish version of the Personal and Social Performance scale in schizophrenia. Schizophrenia Research, 112(13), 181-186.

Baumgartner, J. N., \& Susser, E. (2013). Social integration in global mental health: what is it and how can it be measured? Epidemiology and Psychiatric Sciences, 22(1), 29-37.

Benjet, C., Casanova, L., Borges, G. \& Medina-Mora, M. E. (2013). Impacto de los trastornos psiquiátricos comunes y las condiciones crónicas físicas en el individuo y la sociedad. Salud Pública de México, 55(3), 248-256.

Cervantes, V. H. (2005). Interpretaciones del coeficiente alpha de Cronbach. Avances en medición, 3(1), 9-28.

Chopra, P. K., Couper, J. W., \& Herrman, H. (2004). The assessment of patients with long-term psychotic disorders: application of the WHO Disability Assessment Schedule II. Australian and New Zealand Journal of Psychiatry, 38(9), 753759 .

Chwastiak, L. A., \& Von Korff, M. (2003). Disability in depression and back pain: Evaluation of the World Health Organization Disability Assessment Schedule (WHO DAS II) in a primary care setting. Journal of Clinical Epidemiology, 56(6), 507-514

Crocker, L., \& Algina, J. (1986). Introduction to classical and modern test theory. Florida: Holt, Rinehart and Winston.

Garin, O., Ayuso-Mateos, J. L., Almansa, J., Nieto, M., Chatterji, S., Vilagut, G., ... \& Racca, V. (2010). Validation of the" World Health Organization Disability Assessment Schedule, WHODAS-2" in patients with chronic diseases. Health and Quality of Life Outcomes, 8(1), 51.

Gold, L. H. (2014). DSM-5 and the assessment of functioning: the World Health Organization Disability Assessment Schedule 2.0 (WHODAS 2.0). Journal of the American Academy of Psychiatry and the Law Online, 42(2), 173181.

Goldman, H. H., Skodol, A. E., \& Lave, T. R. (1992). Revising axis V for DSM-IV: a review of measures of social functioning. American Journal of Psychiatry, 149(9), 1148-1156.

Gómez, P., Enders, J., Alvarado, R., Cometto, M., \& Fernandez, A. (2015). Evaluación del funcionamiento psicosocial de los pacientes con trastorno mental Revista de la Facultad de Ciencias Médicas, 72(4), 243-249.

Granger, C. V., Hamilton, B. B., Linacre, J. M., Heinemann, A. W., \& Wright, B. D. (1993). Performance profiles of the functional independence measure. American Journal of Physical Medicine \& Rehabilitation, 72(2), 84-89.

Guerra, M., Ferri, C. P., Sosa, A. L., Salas, A., Gaona, C., Gonzales, V., ... \& Prince, M. (2009). Late-life depression in Peru, Mexico and Venezuela: the 10/66 population-based study. The British Journal of Psychiatry, 195(6), 510-515.

Guilera, G., Gómez-Benito, J., Pino, O., Rojo, J. E., Cuesta, M. J., Martínez-Arán, A., ... \& Rejas, J. (2012). Utility of the World Health Organization Disability Assessment Schedule II in schizophrenia. Schizophrenia Research, 138(2-3), 240-247.

Guilera, G., Gómez-Benito, J., Pino, Ó., Rojo, E., Vieta, E., Cuesta, M. J., ... \& Rejas, J. (2015). Disability in bipolar I disorder: The 36-item World Health Organization Disability Assessment Schedule 2.0. Journal of Affective Disorders, 174, 353-360

Harwood, R. H., Rogers, A., Dickinson, E., \& Ebrahim, S. (1994). Measuring handicap: the London Handicap Scale, a new outcome measure for chronic disease. Quality in Health Care, 3(1), 11-16.

Hays, R. D., Wells, K. B., Sherbourne, C. D., Rogers, W. \& Spritzer, K. (1995). Functioning and well-being outcomes of patients with depression compared with chronic general medical illnesses. Archives of General Psychiatry, 52(1), 11-19.

Lara C, Medina-Mora ME, Borges G, \& Zambrano J. (2007). Social cost of mental disorders: Disability and work days lost. Results from the Mexican survey of psychiatric epidemiology. Salud Mental, 30(5), 4-11.

Matías-Carrelo, L. E., Chávez, L. M., Negrón, G., Canino, G., Aguilar-Gaxiola, S., \& Hoppe, S. (2003). The Spanish translation and cultural adaptation of five mental health outcome measures. Culture, medicine and psychiatry, 27(3), 291-313.

McKibbin, C., Patterson, T. L., \& Jeste, D. V. (2004). Assessing Disability in Older Patients With Schizophrenia: Results From the WHODAS-II. The Journal of Nervous and Mental Disease, 192(6), 405-413.

Mendlowicz, M. V., \& Stein, M. B. (2000). Quality of life in individuals with anxiety disorders. American Journal of Psychiatry, 157(5), 669-682. 
Morosini, P. L., Magliano, L., Brambilla, L., Ugolini, S., \& Pioli, R. (2000). Development, reliability and acceptability of a new version of the DSM-IV Social and Occupational Functioning Assessment Scale (SOFAS) to assess routine social funtioning. Acta Psychiatrica Scandinavica, 101(4), 323-329.

Murray, C. J., Vos, T., Lozano, R., Naghavi, M., Flaxman, A. D., Michaud, C., ... \& Aboyans, V. (2013). Disability-adjusted life years (DALYs) for 291 diseases and injuries in 21 regions, 1990-2010: a systematic analysis for the Global Burden of Disease Study 2010. The Lancet, 380(9859), 2197-2223.

Nunally, J. (1987). Teoría psicométrica. Ciudad de México: Trillas.

Olfson, M., Fireman, B., Weissman, M. M., Leon, A. C., Sheehan, D. V., Kathol, R. G., ... \& Farber, L. (1997). Mental disorders and disability among patients in a primary care group practice. American Journal of Psychiatry, 154(12), 17341740 .

Organización Mundial de la Salud \& Organización Panamericana de la Salud. (2001). Clasificación Internacional del Funcionamiento, de la Discapacidad y de la Salud: CIF. Organización Mundial de la Salud.

Romera, I., Perez, V., Menchón, J. M., Delgado-Cohen, H., Polavieja, P., \& Gilaberte, I. (2010). Social and occupational functioning impairment in patients in partial versus complete remission of a major depressive disorder episode. A six-month prospective epidemiological study. European Psychiatry, 25(1), 58-65.

Sabbag, S., Twamley, E. W., Vella, L., Heaton, R. K., Patterson, T. L., \& Harvey, P. D. (2012). Predictors of the accuracy of self-assessment of everyday functioning in people with schizophrenia. Schizophrenia Research, 137(1-3), 190-195.

Sartorius, N., \& Üstün, T.B. (1995). The World Health Organization quality of life assessment (WHOQOL): Position paper from the World Health Organization. Social Science \& Medicine, 41(10), 1403-1409.

Spitzer, R. L., Gibbon, M., \& Endicott, J. (2000). Global assessment scale (GAS), global assessment of functioning (GAF) scale, social and occupational functioning assessment scale (SOFAS). Handbook of psychiatric measures. Washington: American Psychiatric Association, 96-100.
Stein, M. B., Walker, J. R., Hazen, A. L., \& Forde, D. R. (1997). Full and partial posttraumatic stress disorder: findings from a community survey. American Journal of Psychiatry, 154(8), 1114-1119.

Üstün, T. B., Chatterji, S., Kostanjsek, N., Rehm, J., Kennedy, C., Epping-Jordan, J., ... \& Pull, C. (2010). Developing the World Health Organization disability assessment schedule 2.0. Bulletin of the World Health Organization, 88(11), 815-823.

Vázquez-Barquero, J. L., Vázquez, B. E., Herrera, C. S., Saiz, J., Uriarte, M., Morales, F., ... \& Ustün, T. B. (1999). Spanish version of the new World Health Organization Disability Assessment Schedule II (WHO-DAS-II): initial phase of development and pilot study. Cantabria disability work group. Actas Españolas de Psiquiatria, 28(2), 77-87.

Vázquez-Barquero, J. L., Herrera S, Vázquez E, Gaite L. (2006). Cuestionario para la Evaluación de Discapacidad de la Organización Mundial de la Salud:(versión española del World Health Organization Disability Assessment Schedule II): WHO-DAS II. Madrid: Ministerio de Trabajo y Asuntos Sociales.

Velligan, D., Diamond, P., Maples, N., Mintz, J., Li, X., Glahn, D., \& Miller, A. (2008). Comparing the efficacy of interventions that use environmental supports to improve outcomes in patients with schizophrenia. Schizophrenia Research, 102(1-3), 312-319.

Vos, T., Flaxman, A. D., Naghavi, M., Lozano, R., Michaud, C., Ezzati, M., ... \& Abraham, J. (2013). Years lived with disability (YLDs) for 1160 sequelae of 289 diseases and injuries 1990-2010: a systematic analysis for the Global Burden of Disease Study 2010. The Lancet, 380(9859), 2163-2196.

Ware Jr, J. E., Kosinski, M., \& Keller, S. D. (1996). A 12-Item Short-Form Health Survey: construction of scales and preliminary tests of reliability and validity. Medical Care, 34(3), 220-233.

World Health Organization (Ed.). (1995). Clasificación estadistica internacional de enfermedades y problemas relacionados con la salud (Décima revisión). Washington, D.C: OPS, Oficina Sanitaria Panamericana, Oficina Regional de la Organización Mundial de la Salud. 